\title{
TINGKAT KEPUASAN PESERTA DIDIK PADA PEMBELAJARAN MATEMATIKA DI MASA PANDEMI COVID-19
}

\section{STUDENTS' SATISFACTION LEVEL IN LEARNING MATHEMATICS IN THE PANDEMIC COVID-19}

\author{
MUHAMMAD SAFAK \\ SMPN 1 Lumajang
}

\begin{abstract}
During the Covid-19 pandemic, there was a change in teaching and learning activities for students and teachers from face-to-face learning to distance learning (PJJ) activities. Students satisfaction in the implementation of PJJ is determined by the design of teaching materials and teacher services. The purpose of the study was to analyze the level of students satisfaction in learning mathematics during the pandemic. The research was conducted at SMP Negeri 1 Lumajang using a descriptive method with survey techniques. Collecting data using a questionnaire with googleform. The results showed that the level of student satisfaction with learning during the pandemic was $86.50 \%$ (very satisfied). The student satisfaction includes the teacher's ability to compose: contextual material (79.19\%), accuracy of teaching materials (89.17\%), suitability of material (88.33\%), motivating (90.83\%), punctuality (85\%), encouraging (91.67\%), evaluating (87\%), preparing programs (85.83\%), communicating (81.67\%), teacher's concern (89.17\%), responding (88.33\%), involvement (87.50\%), good teaching aids (82.50\%), material access $(85.00 \%)$, task access (84.17\%).
\end{abstract}

Abstrak. Pada masa pandemi Covid-19, terjadi perubahan kegiatan belajar mengajar peserta didik dan guru dari pembelajaran tatap muka ke kegiatan Pembelajaran Jarak Jauh (PJJ). Kepuasan peserta didik dalam implementasi PJJ sangat ditentukan oleh desain bahan ajar dan pelayanan guru. Tujuan penelitian ini untuk menganalisis tingkat kepuasan peserta didik dalam pembelajaran matematika selama masa pandemi. Penelitian dilakukan di SMP Negeri 1 Lumajang. Metode yang digunakan dalam penelitian adalah deskriptif dengan teknik survei. Pengumpulan data menggunakan kuesioner dengan googleform. Setelah proses pembelajaran selesai, dilakukan survey untuk mengetahui tingkat kepuasaan peserta didik berdasarkan indikator dari setiap dimensi yang mempengaruhi tingkat kepuasan. Hasil penelitian menunjukkan Tingkat kepuasaan peserta didik terhadap pembelajaran di masa pandemi sebesar $86,50 \%$. Kepuasan peserta didik tersebut meliputi kemampuan guru menyusun: materi kontekstual (79,19\%), ketepatan bahan ajar (89,17\%), kesesuaian materi (88,33\%), memotivasi (90,83\%), ketepatan waktu (85\%), menyemangati $(91,67 \%)$, mengevaluasi $(87 \%)$, menyusun program $(85,83 \%)$, berkomunikasi $(81,67 \%)$, kepedulian $(89,17 \%)$, respon $(88,33 \%)$, peran aktif $(87,50 \%)$, bahan ajar menarik (82,50\%), akses materi (85,00\%), akses tugas (84,17\%), secara umum tingkat kepuasan peserta didik dalam pembelajaran matematika di masa pandemi berjalan sangat baik. Aspek yang menonjol adalah memotivasi dan menyemangati dan aspek yang perlu diperbaiki adalah materi kontekstual.

Keywords: $\quad$ student satisfaction level, distance learning, mathematics learning

Kata kunci: $\quad$ tingkat kepuasan peserta didik, PJJ, pembelajaran matematika

(*) Corresponding Author: Safaku.no1903@gmail.com

How to Cite: Safak, M. (2021). Tingkat Kepuasan Peserta Didik Pada Pembelajaran Matematika Di Masa Pandemi Covid-19. Jurnal Lingkar Mutu Pendidikan, 18 (1), 73-80. https://doi.org/10.54124/jlmp.v18i1.8

\section{PENDAHULUAN}

Di masa pandemi Covid-19, terjadi perubahan kegiatan belajar mengajar. Kondisi ini mengubah peserta didik dan guru untuk melakukan kegiatan pembelajaran dengan jarak jauh yaitu berada di rumah masing-masing. Hal inilah yang membuat guru harus lebih kreatif sehingga kegiatan pembelajaran jarak jauh tidak akan menjadi halangan bagi peserta didik untuk tetap mendapatkan hak belajarnya. 
Sebagai pendidik dituntut untuk menyediakan bahan ajar yang tepat sehingga proses belajar jarak jauh bagi peserta didik dapat berjalan dengan baik, meskipun harus kita sadari betapapun bahan belajar itu telah disusun supaya dapat dicerna sendiri oleh peserta didik, kesulitan-kesulitan yang dihadapi peserta didik waktu belajar secara mandiri tetap akan selalu ada.

Mengajar bukan hanya perkara soal pengetahuan yang mumpuni. Mengajar juga harus rela untuk menjadi fasilitator yang baik bagi peserta didiknya. Seorang guru harus mampu menjadi pembimbing dan motivator ulung bagi peserta didik. Guru harus melibatkan peserta didik secara aktif sehingga proses pembimbingan dapat berjalan dengan efektif. Pemberian motivasi menjadi aspek penting bagi seorang guru yang harus dilakukan. Tidak semua peserta didik memiliki motivasi yang kuat dalam mengikuti kegiatan belajar mengajar, apalagi dalam pembelajaran jarak jauh pada masa pandemi Covid-19 saat ini, peserta didik dan guru tidak berada dalam waktu dan ruang yang sama sehingga dimungkinkan juga lemahnya semangat diakibatkan kurangnya motivasi yang diberikan oleh guru terhadap peserta didik (Hartono 2013, 17)

Dalam PJJ diperlukan kolaborasi yang baik antara bahan ajar dan pelayanan guru sehingga peserta didik dapat terpuaskan dalam proses pembelajaran di masa pandemi Covid-19 saat ini. Tentu bagi beberapa peserta didik yang sudah terbiasa dengan pembelajaran konvesional akan merasakan perbedaan sehingga memunculkan rasa kurang nyaman.

Berdasarkan latar belakang di atas, maka rumusan masalah dan tujuan dari penelitian ini adalah untuk mengetahui tingkat kepuasan peserta didik pada pembelajaran matematika kelas VIII di masa pandemi Covid-19 di SMP Negeri 1 Lumajang. Manfaat Penelitian ini dapat digunakan sebagai data empirik bagi peningkatan kualitas pengajaran di SMP khususnya yang berkaitan dengan mata pelajaran Matematika. Sebagai bahan kajian untuk merumuskan inovasi pembelajaran pada mata pelajaran yang lain, serta berguna untuk peningkatan kualitas pendidik.

Oliver menyatakan kepuasan pelanggan adalah "perasaan senang atau kecewa yang didapatkan seseorang dari membandingkan antara kinerja (atau hasil) produk yang dipersepsikan dengan ekspektasinya" (Zulkarnaen 2012, 78). Peserta didik dalam proses pembelajaran harus merasakan senang dalam setiap pembelajaran meskipun dalam masa pandemi Covid-19.

Kepuasan sudah menjadi tujuan dari adanya pelayanan dan konsep yang utama dari sebuah manajemen/ sekolah. Menurut Sopiatin $(2010,33)$ kepuasan peserta didik adalah suatu sikap yang diperlihatkan oleh peserta didik, baik sikap positif maupun sikap negatif atas adanya kesesuaian antara harapan mereka terhadap pelayanan proses belajar mengajar yang diterimanya.

Berry dan Parasurama dalam Sopiatin $(2010,40)$ menjelaskan bahwa faktor-faktor yang dapat menentukan kepuasan peserta didik yang dapat digunakan sebagai indikator kepuasan peserta didik dalam penelitian ini yaitu meliputi keandalan, daya tanggap, kepastian, empati, dan berwujud. Keandalan berhubungan dengan kemampuan sekolah dalam memberikan pelayanan proses belajar mengajar yang bermutu sesuai dengan peserta didik. Daya tanggap adalah kesediaan personil sekolah untuk mendengar dan mengatasi keluhan peserta didik. Kepastian dapat diartikan sebagai suatu keadaan yang pasti. Empati dalam pemahaman psikologi adalah keadaan mental yang membuat seseorang merasa dirinya di keadaan perasaan orang lain. Berwujud dalam dunia pendidikan berhubungan dengan aspek fisik sekolah yang diperlukan untuk menunjang proses belajar mengajar.

Menurut Daryanto $(2017,96)$ pembelajaran jarak jauh (PJJ) adalah pembelajaran dengan menggunakan suatu media yang memungkinkan terjadi interaksi antar pengajar dan pembelajar. Pendidikan jarak jauh memerlukan alat telekomunikasi yang interaktif untuk bisa menghubungkan keduanya.

Pembelajaran dalam pendidikan jarak jauh menggunakan waktu yang sangat fleksibel. Peserta didik dapat mengakses materi kapan saja dan dimana saja. Mereka bertanggungjawab pada diri masing-masing, dan ini bukanlah merupakan suatu pilihan yang mudah bagi peserta didik dan juga pengajar. Maka dari itu pembelajaran jarak jauh memiliki kekurangan sekaligus kelebihannya.

Tingkat kepuasan peserta didik terhadap pelayanan proses pembelajaran di kelas terindikasi ketika harapan peserta didik dapat terpenuhi atau mungkin terlampaui. Peningkatan kemampuan yang dimiliki peserta didik, sudah pasti didapatkan ketika peserta didik menggunakan pelayanan dalam proses pembelajaran. Tercapainya kepuasan akan memberikan penilaian yang baik dari peserta didik 
kepada guru ataupun pihak sekolah. Jika seorang guru berorientasi pada kepuasan peserta didik, maka seorang guru harus berbenah diri dalam meningkatkan kepercayaan peserta didik, meningkatkan daya tangkap yang baik agar tidak mengulangi kesalahan, cepat dan tanggap menangani keluhan, dan memberikan kepastian dalam pelayanan dan berempati pada masalah yang dialami oleh peserta didik serta lebih meningkatkan kemampuan diri untuk mempermudah dalam memfasilitasi masalahmasalah yang dihadapi oleh peserta didik.

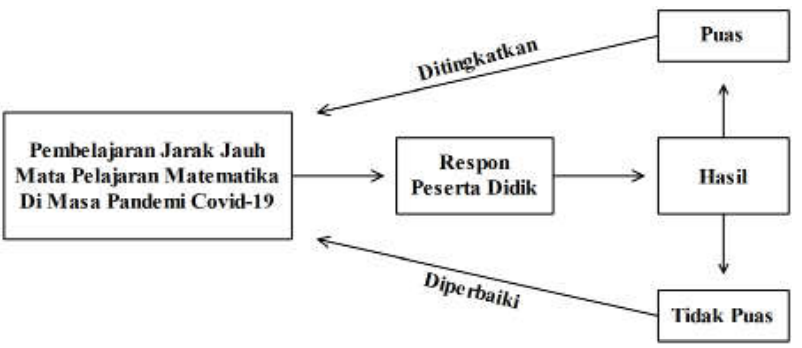

Gambar 1. Kerangka Berpikir

\section{METODOLOGI PENELITIAN}

Metode penelitian ini adalah analisis deskriptif dengan teknik survey menggunakan kuesioner melalui googleform. Penelitian ini dilakukan di SMP Negeri 1 Lumajang Jalan HOS Cokroaminoto Nomor 159 Tompokersan Lumajang Jawa Timur. Waktu penelitian seperti pada tabel di bawah ini.

Tabel 1. Waktu Penelitian

\begin{tabular}{|c|c|c|c|c|c|}
\hline \multirow{2}{*}{ Kegiatan } & \multicolumn{5}{|c|}{ Tahun 2020} \\
\hline & April & Mei & Juni & Juli & Agustus \\
\hline \multicolumn{6}{|l|}{ Penyusunan Bab I } \\
\hline \multicolumn{6}{|l|}{ Penyusunan Bab II } \\
\hline \multicolumn{6}{|l|}{ Penyusunan Bab III dan survei } \\
\hline \multicolumn{6}{|l|}{ Penyusunan hasil penelitian } \\
\hline Revisi dan Seminar & & & & & \\
\hline
\end{tabular}

Populasi target dalam penelitian ini seluruh peserta didik kelas VIII SMP Negeri 1 Lumajang tahun pelajaran 2019-2020 yang berjumlah 257 peserta didik. Sedangkan populasi terjangkau adalah peserta didik kelas VIII C, D, E, F, G, dan H yang berjumlah 193 peserta didik, dimana pengajar melaksanakan proses pembelajaran di kelas tersebut. Adapun rinciannya sebagai berikut.

Tabel 2. Jumlah Peserta Didik Kelas VIII

\begin{tabular}{lccc}
\hline \multirow{2}{*}{ Kelas } & \multicolumn{3}{c}{ Jumlah Peserta Didik } \\
\cline { 2 - 4 } & $\mathrm{L}$ & $\mathrm{P}$ & Total \\
\hline VIII C & 16 & 16 & 32 \\
VIII D & 16 & 16 & 32 \\
VIII E & 16 & 16 & 32 \\
VIII F & 17 & 16 & 33 \\
VIII G & 16 & 16 & 32 \\
VIII H & 16 & 16 & 32 \\
Jumlah & 96 & 97 & 193 \\
\hline
\end{tabular}

Pengambilan sampel penelitian ini menggunakan teknik random sampling yang diambil sebanyak $20 \%$ dari populasi terjangkau yaitu 30 . Pengumpulan data merupakan proses pengadaan data untuk keperluan suatu penelitian yang merupakan langkah penting dalam metode ilmiah.

Pengolahan data menggunakan langkah-langkah editing, coding, skoring dan tabulating. Setelah angket disebar dan diisi oleh peserta didik, kemudian dilakukan pengecekan satu per satu meliputi kelengkapan pengisian, penjelasan penulisan angket dan kebenaran pengisian angket. Tahap 
berikutnya pemberian angka atau huruf pada angket untuk mempermudah dalam pengumpulan dan pengolahan data yang telah diisi oleh peserta didik yang menjadi responden. Tahap ketiga pemberian skor atau nilai pada setiap butir pertanyaan yang terdapat dalam angket. Dalam skala penelitian ini terdapat 4 pilihan alternatif jawaban, yaitu: Sangat puas, puas, tidak puas, sangat tidak puas. Langkah terakhir dalam pengumpulan data yaitu dengan memasukkan data ke tabel agar dapat mengetahui hasilnya.

Angket yang digunakan untuk penelitian ini harus diuji dulu tingkat validitas dan reliabilitasnya agar instrumen yang digunakan dapat diandalkan. Hasilnya dari 15 butir pertanyaan yang diujikan, 13 butir soal dengan validitas tinggi dan 2 butir soal dengan validitas sangat tinggi. Uji reliabilitas instrumen, hasilnya dari 15 butir pertanyaan yang diujikan, reliabilitas butir soal bagus. Sehingga instrumen tersebut dapat digunakan.

Teknik analisis data digunakan untuk memberikan keterangan data yang telah dikumpulkan agar semua data dapat dipahami dengan baik, data yang telah dikumpulkan akan dianalisis dengan menggunakan deskriptif analisis. Analisis ini dimaksudkan untuk mengetahui kondisi atau gambaran variabel yang diteliti berdasarkan tanggapan responden.

Untuk memberikan interpretasi dari hasil perhitungan yang diperoleh, digunakanlah pedoman untuk interpretasi data sebagai berikut. Sangat puas, jika nilai berada pada interval $75,1 \%-100 \%$. Puas, jika nilai berada pada interval 50,1\% - 75\%. Tidak puas, jika nilai berada pada interval 25,1\% $50 \%$. Sangat tidak puas, jika nilai berada pada interval 0\% - 25\%.

Tingkat kepuasan peserta didik dalam penelitian ini dituangkan dalam lima indikator yaitu keandalan, daya tanggap, kepastian, empati, dan berwujud. Kelima indikator tersebut dijabarkan dalam 3 sub indikator. Adapun kisi-kisi instrumen yang akan disebarakan ke peserta didik/ responden adalah sebagai berikut.

Tabel 3. kisi-kisi instrumen survei

\begin{tabular}{|c|c|c|c|}
\hline No & Dimensi & Penjabaran Indikator & No. Soal \\
\hline 1 & Keandalan & $\begin{array}{ll}\text { - } & \text { Kemampuan guru dalam menyusun materi kontekstual (materi kontekstual) } \\
\text { - } & \text { Kemampuan guru dalam menyusun bahan ajar yang tepat (ketepatan bahan } \\
\text { - } & \text { Kesar) } \\
& \text { Kesesuaian materi dengan kurikulum (kesesuaian materi) }\end{array}$ & $1,2,3$ \\
\hline 2 & Daya tanggap & $\begin{array}{ll}\text { - } & \text { Kemampuan guru dalam memotivasi peserta didik (memotivasi) } \\
\text { - } & \text { Ketepatan waktu dalam merespon peserta didik (ketepatan waktu) } \\
\text { - } & \text { Semangat guru dalam proses pembelajaran (menyemangati) }\end{array}$ & $4,5,6$ \\
\hline 3 & Kepastian & $\begin{array}{ll}\text { - } & \text { Kesesuaian latihan evaluasi/ tugas dengan materi yang diberikan } \\
& \text { (mengevaluasi) } \\
\text { - } & \text { Kepastian dalam menyusun program pembelajaran (menyusun program) } \\
\text { - } & \text { kemudahan peserta didik untuk berkomunikasi dengan guru (berkomunikasi) } \\
\end{array}$ & $7,8,9$ \\
\hline 4 & Empati & $\begin{array}{ll}\text { - } & \text { Kepedulian guru terhadap peserta didik yang mengalami kesulitan. } \\
& \text { (kepedulian) } \\
\text { - } & \text { Respon guru terhadap kritik, saran, pertanyaan dari peserta didik (respon) } \\
\text { - } & \text { Kemampuan guru dalam menumbuhkan peran aktif peserta didik (peran aktif) }\end{array}$ & $10,11,12$ \\
\hline 5 & Berwujud & $\begin{array}{ll}\text { - } & \text { Kemampuan guru dalam menyusun bahan ajar yang menarik (bahan ajar } \\
& \text { menarik) } \\
\text { - } & \text { Kemudahan akses peserta didik dalam mendapatkan materi (akses materi) } \\
\text { - } & \text { Kemudahan akses peserta didik dalam mengumpulkan tugas (akses tugas) }\end{array}$ & $13,14,15$ \\
\hline
\end{tabular}

\section{HASIL DAN PEMBAHASAN}

Berdasarkan permasalahan sebagaimana dijelaskan pada latar belakang di atas, guru berinovasi pada pembelajaran matematika di masa pandemi Covid-19 melalui beberapa aplikasi yang dapat digunakan untuk pembelajaran, diantaranya whatsapp, google form, google drive, instagram, quizziz hingga web e-learning sekolah. Selama masa pandemi materi yang belum tersampaikan adalah bangun ruang sisi datar, statistika, dan peluang. Materi-materi ini akan dibagi ke dalam beberapa kali pertemuan (kegiatan pembelajaran jarak jauh/ PJJ). Sumber daya yang digunakan pun diusahakan yang mudah digunakan oleh peserta didik. Berikut pembagian materi dan sumber daya yang digunakan. 
Tabel 4. Pembagian materi dan sumber daya yang digunakan

\begin{tabular}{|c|c|c|c|}
\hline No & Materi & Sub Materi & Sumber Daya Pembelajaran \\
\hline \multirow[t]{5}{*}{1} & \multirow{5}{*}{$\begin{array}{l}\text { Bangun } \\
\text { Ruang Sisi } \\
\text { Datar }\end{array}$} & Kubus & \multirow{5}{*}{$\begin{array}{l}\text { WhatsApp } \\
\text { Google drive } \\
\text { Quizizz } \\
\text { Google Form } \\
\text { Instagram }\end{array}$} \\
\hline & & Balok & \\
\hline & & Prisma & \\
\hline & & Limas & \\
\hline & & Bangun Ruang Gabungan & \\
\hline \multirow[t]{4}{*}{2} & \multirow[t]{4}{*}{ Statistika } & Analisis Data & \multirow{4}{*}{$\begin{array}{l}\text { WhatsApp } \\
\text { Google Form } \\
\text { Web e-learning sekolah } \\
\text { Instagram }\end{array}$} \\
\hline & & Mean & \\
\hline & & Median, Modus & \\
\hline & & Ukuran Penyebaran data & \\
\hline \multirow[t]{3}{*}{3} & \multirow[t]{3}{*}{ Peluang } & Peluang Empirik & \multirow{3}{*}{$\begin{array}{l}\text { WhatsApp } \\
\text { Google Form } \\
\text { Web e-learning sekolah } \\
\text { Instagram }\end{array}$} \\
\hline & & Peluang Teoretik & \\
\hline & & Hubungan Antara Kedua Peluang & \\
\hline
\end{tabular}

Setiap materi dirancang dengan tahapan operasional yang hampir sama dikarenakan kejadian ini begitu mendadak, namun tanpa meninggalkan inti dari pembelajaran itu sendiri. Secara garis besar tahapan operasional pembelajaran jarak jauh untuk mata pelajaran matematika adalah sebagai berikut.

Tabel 5. langkah-langkah PJJ matematika

\begin{tabular}{|c|c|}
\hline Fase 1 & $\begin{array}{l}\text { 1. Guru memberikan materi dalam bentuk lembar kerja. } \\
\text { 2. Guru mengunggah materi ke dalam google drive atau laman e-learning sekolah }\end{array}$ \\
\hline Fase 2 & $\begin{array}{l}\text { 1. Peserta didik mulai mengerjakan lembar kerja serta mencari materi dari berbagai sumber yang ada } \\
\text { 2. Guru memberikan semangat, masukan dan dorong kepada peserta didik } \\
\text { 3. Peserta didik mengunggah lembar kerja yang sudah terisi ke dalam google form atau laman e-learning sekolah }\end{array}$ \\
\hline Fase 3 & $\begin{array}{l}\text { 1. Guru mengoreksi hasil lembar kerja peserta didik } \\
\text { 2. Guru memberi umpan balik serta penguatan hasil kerja peserta didik dengan cara memberi kunci jawaban lembar kerja } \\
\text { serta menjelaskan (tanya jawab) melalui instagram live }\end{array}$ \\
\hline Fase 4 & $\begin{array}{l}\text { 1. Guru memberi latihan soal-soal melalui google form atau quizziz } \\
\text { 2. Peserta didik mengerjakan latihan soal-soal yang diberikan oleh guru }\end{array}$ \\
\hline
\end{tabular}

Semua materi berupa lembar kerja peserta didik yang melalui pendekatan komunikatif agar peserta didik taat prosedur dan dapat belajar sendiri, hal ini sesuai dengan penelitian yang dilakukan oleh Yuliati $(2017,202)$.

Materi disimpan di dalam google drive dan juga laman e-learning sekolah. Pemilihan kedua tempat ini menggunakan prinsip efisiensi dengan alasan agar materi tidak hilang dan peserta didik dapat mudah mengakses materi dan tugas tersebut, senada dengan hasil penelitian (Latip 2020, 111). Alamat tautan google drive dan pemberitahuan bahwa materi telah ada, diinformasikan dalam whatsapp grup serta bagian paling bawah dalam lembar kerja peserta didik.

Jika terdapat peserta didik yang mengalami kesulitan dalam mempelajari lembar kerja dan juga pengerjaan soal-soalnya, peserta didik dapat menghubungi guru melalui whatsapp grup. Selain itu whatsapp grup juga digunakan oleh guru untuk memberi semangat, motivasi serta masukkan bagi peserta didik yang mengalami kesulitan dalam belajar. Komunikasi antara peserta didik dan guru dapat dilakukan tanpa dibatasi oleh jarak, tempat, dan waktu. Tentunya ini juga sesuai dengan hasil penelitian yang dilakukan (Alaby 2020, 280) sehingga komunikasi dua arah diharapkan terus berlangsung.

Lembar kerja yang telah dikerjakan kemudian dikirim melalui google form ataupun laman e-learning sekolah dalam bentuk format $p d f, j p g$, atau doc untuk kemudian dinilai oleh guru. Guru memberikan dua tempat pengumpulan lembar kerja agar peserta didik dapat memilih mana tempat yang mudah bagi mereka untuk mengumpulkan lembar kerja tersebut. Guru selalu mengontrol dan terus mengingatkan peserta didik yang belum melakukan pembelajaran atau pengumpulan lembar kerja, karena salah satu prinsip PJJ adalah kemandirian/Independent learning (Daryanto and Karim 2017, 104) namun karena umur peserta didik yang masih belia sehingga kemandirian masih harus dibimbing dan terus diingatkan. 
Setelah peserta didik mengumpulkan lembar kerjanya, guru memberikan umpan balik dengan cara memberikan pembahasan (kunci jawaban) secara tertulis kemudian dibagikan di whatsapp grup dalam bentuk pdf. Guru meminta peserta didik untuk mempelajari dan mencatat bagian-bagian yang masih membingungkan atau belum dipahami. Selanjutnya, guru menentukan waktu untuk melakukan siaran langsung melalui instagram guna memberikan penjelasan secara lisan terkait bagian-bagian yang ada di lembar kerja yang sudah berisi pembahasan, kegiatan ini juga bisa digunakan untuk tanya jawab, diskusi, atau sekedar menanyakan kabar dengan peserta didik.

Ketika proses pemberian materi dirasa sudah cukup dipahami oleh peserta didik. Guru merancang dan melaksanakan penilaian sesuai dengan materi yang diajarkan. Dalam hal ini, media yang digunakan adalah google form. Tautan yang memuat penilaian disebar melalui whatsapp grup.

Untuk mengetahui tingkat kepuasan peserta didik pada pembelajaran matematika selama masa pandemi, dilakukan survei. Hampir mirip seperti lembaga/instansi lain survei tingkat kepuasan ini mengukur kepuasan peserta didik berdasarkan pelayanan yang diberikan oleh guru matematika selama pembelajaran di masa pandemi. Survei ini mengukur 5 dimensi dalam pemberian pelayanan yaitu meliputi keandalan, daya tanggap, kepastian, empati, dan berwujud. Kelima dimensi ini kemudian dijabarkan ke dalam lima belas indikator, berikut rincian hasil penelitiannya.

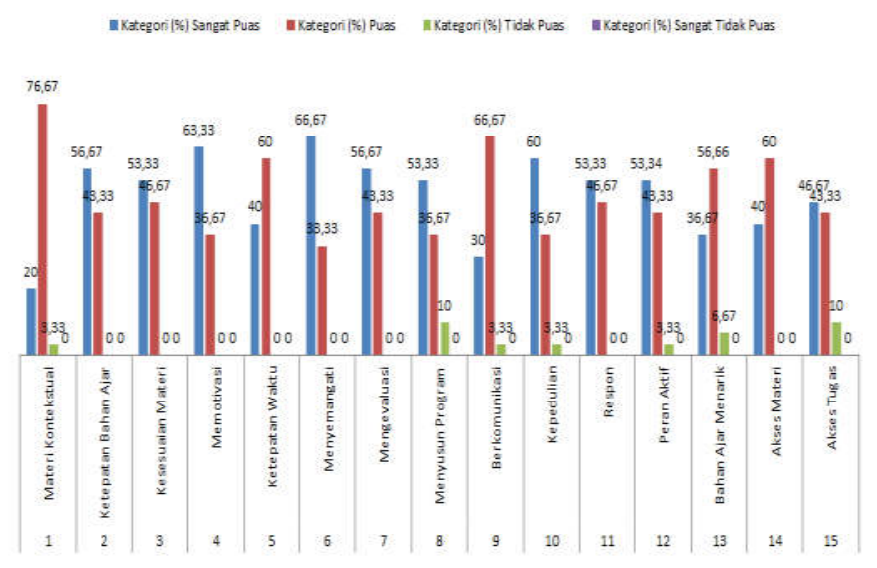

Gambar 2. Diagram batang hasil penelitian per indikator

Dari diagram di atas terbaca bahwa terdapat 10 aspek prosentase sangat puas lebih tinggi dibandingkan yang lain, yaitu aspek ketepatan bahan ajar, kesesuaian materi, memotivasi, menyemangati, mengevaluasi, menyusun program, kepedulian, respon, peran aktif dan akses tugas. Sedangkan aspek materi kontekstual, ketepatan waktu, berkomunikasi, bahan ajar menarik dan akses materi prosentase puas lebih tinggi dibandingkan tingkat kepuasan yang lain. Masih terdapat aspek dimana responden memilih tidak puas, yaitu terdapat pada aspek materi kontekstual, menyusun program, berkomunikasi, kepedulian, peran aktif, bahan ajar menarik dan akses tugas.

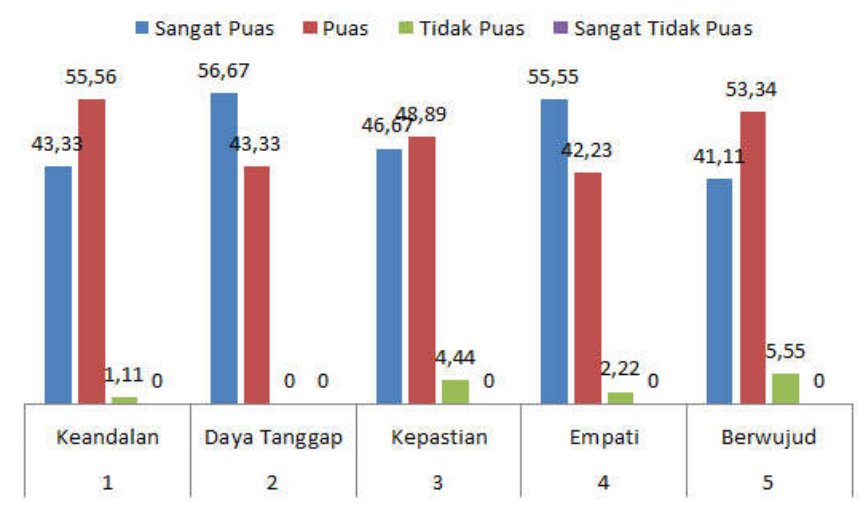

Gambar 3. Diagram batang hasil penelitian per indikator

Diagram di atas adalah hasil penelitian terkait kategori kepuasan berdasarkan kelima indikator. Hasilnya terlihat bahwa hanya Indikator daya tanggap dimana peserta didik tidak ada yang merasa 
tidak puas, sedangkan keempat indikator yang lain masih ada peserta didik yang merasa tidak puas. Namun kategori sangat puas dan puas masih jauh lebih banyak dibandingkan peserta didik yang merasa tidak puas.

Setelah hasil surveidiperoleh, dilakukan analisis datatersebutuntuk kemudian diinterprestasikannya ke dalam tingkat kepuasaan peserta didik selama proses pembelajaran matematika di masa pandemi pada semester gasal tahun pelajaran 2019/2020. Adapun hasil yang diperoleh adalah rata-rata tingkat kepuasan per butir indikator menunjukkan sangat puas. Berikut rinciannya dalam bentuk tabel. Tabel 6. prosentase tingkat kepuasan per butir soal

\begin{tabular}{|c|c|c|c|}
\hline No & Butir Soal & $\begin{array}{c}\text { Prosentase } \\
\text { tingkat kepuasan }\end{array}$ & Keterangan \\
\hline 1 & Kemampuan guru dalam menyusun materi kontekstual (materi kontektual) & $79,19 \%$ & Sangat puas \\
\hline 2 & Kemampuan guru dalam menyusun bahan ajar yang tepat (ketepatan bahan ajar) & $89,17 \%$ & Sangat puas \\
\hline 3 & Kesesuaian materi dengan kurikulum (kesesuaian) & $88,33 \%$ & Sangat puas \\
\hline 4 & Kemampuan guru dalam memotivasi peserta didik (memotivasi) & $90,83 \%$ & Sangat puas \\
\hline 5 & Ketepatan waktu dalam merespon peserta didik (ketepatan waktu) & $85,00 \%$ & Sangat puas \\
\hline 6 & Semangat guru dalam proses pembelajaran (menyemangat) & $91,67 \%$ & Sangat puas \\
\hline 7 & Kesesuaian latihan evaluasi/ tugas dengan materi yang diberikan. (mengevaluasi) & $89,17 \%$ & Sangat puas \\
\hline 8 & Kepastian dalam menyusun program pembelajaran (menyusun program) & $85,83 \%$ & Sangat puas \\
\hline 9 & kemudahan peserta didik untuk berkomunikasi dengan guru (berkomunikasi) & $81,67 \%$ & Sangat puas \\
\hline 10 & Kepedulian guru terhadap peserta didik yang mengalami kesulitan (kepedulian) & $89,17 \%$ & Sangat puas \\
\hline 11 & Respon guru terhadap kritik, saran, pertanyaan dari peserta didik (respon) & $88,33 \%$ & Sangat puas \\
\hline 12 & Kemampuan guru dalam menumbuhkan peran aktif peserta didik (peran aktif) & $87,50 \%$ & Sangat puas \\
\hline 13 & Kemampuan guru dalam menyusun bahan ajar yang menarik (bahan ajar menarik) & $82,50 \%$ & Sangat puas \\
\hline 14 & Kemudahan akses peserta didik dalam mendapatkan materi (akses materi) & $85,00 \%$ & Sangat puas \\
\hline 15 & Kemudahan akses peserta didik dalam mengumpulkan tugas (akses tugas) & $84,17 \%$ & Sangat puas \\
\hline
\end{tabular}

Kelima belas butir pernyataan merupakan penjabaran dari lima dimensi yang akan menentukan tingkat kepuasan peserta didik. Dari hasil survei tersebut kemudian dianalisis untuk mengetahui tingkat kepuasan peserta didik berdasarkan setiap dimensi. Diperoleh hasil bahwa aspek yang sangat menonjol tingkat kepuasannya adalah kemampuan guru dalam memotivasi peserta didik $(90,83 \%)$ dan semangat guru dalam proses pembelajaran (91,67\%). Adapun aspek yang kurang dan perlu ditingkatkan oleh guru adalah kemampuan guru dalam menyusun materi kontekstual (79,19\%).

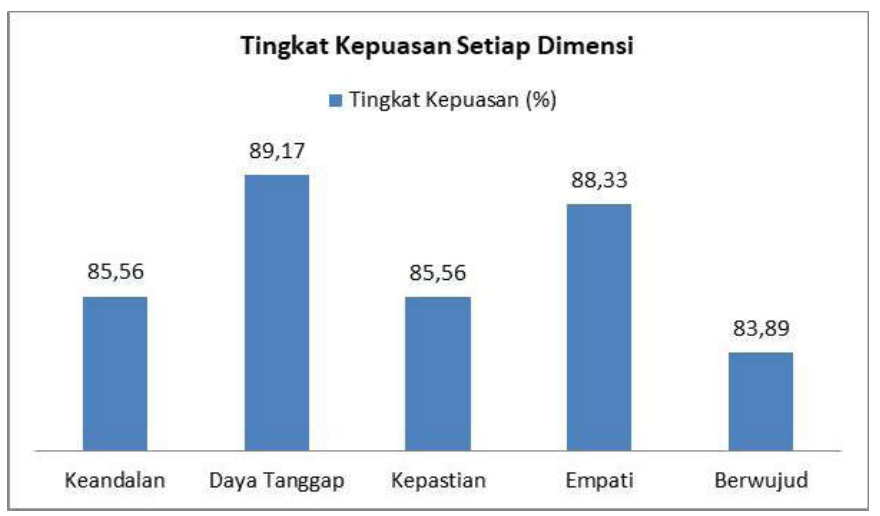

Gambar 4. Diagram batang tingkat kepuasan per dimensi

Dari hasil di atas, kelima belas aspek tersebut diolah untuk mengetahui tingkat kepuasaan setiap dimensi. Hasil tingkat kepuasan peserta didik dalam setiap dimensi disajikan dalam diagram di atas. Hasilnya kelima dimensi tersebut menunjukkan nilai kepuasan di atas $80 \%$ yang artinya bahwa peserta didik merasa sangat puas. Tingkat kepuasaan setiap dimensi selanjutnya diolah sehingga diperoleh hasil tingkat kepuasan peserta didik dalam pembelajaran matematika di masa pandemi Covid-19 adalah sebesar $86,50 \%$ yang berarti bahwa tingkat kepuasan peserta didik menunjukkan sangat puas. 


\section{SIMPULAN DAN SARAN}

Berdasarkan paparan dan hasil survei yang telah dilakukan dan dibahas dalam bab pembahasan, maka diperoleh hasil bahwa pembelajaran matematika kelas VIII di SMP Negeri 1 Lumajang selama masa pandemi Covid-19 menunjukkan tingkat kepuasaan peserta didik sebesar 86,50\%. Kepuasan peserta didik tersebut meliputi kemampuan guru menyusun: materi kontekstual $(79,19 \%)$, ketepatan bahan ajar (89,17\%), kesesuaian materi (88,33\%), memotivasi $(90,83 \%)$, ketepatan waktu (85\%), menyemangati $(91,67 \%)$, mengevaluasi $(87 \%)$, menyusun program $(85,83 \%)$, berkomunikasi $(81,67 \%)$, kepedulian $(89,17 \%)$, respon $(88,33 \%)$, peran aktif $(87,50 \%)$, bahan ajar menarik $(82,50 \%)$, akses materi $(85,00 \%)$, akses tugas $(84,17 \%)$,

\section{PUSTAKA ACUAN}

Alaby, Muhammad Awin. "Media Sosial Whatsapp Sebagai Media Pembelajaran Jarak Jauh Mata Kuliah ISBD." Jurnal IImu Sosial dan Humaniora (Ganaya), 2020.

Daryanto, and Syaiful Karim. Pembelajaran abad 21. Yogyakarta: Gava Media, 2017.

Hartono, Rudi. Ragam Model Mengajar yang Mudah Diterima Murid. Yogyakarta: DIVA Press, 2013.

Latip, Abdul. "Peran Literasi Teknologi Informasi dan Komunikasi Pada Pembelajaran Jarak Jauh di Masa Pandemi Covid-19." Jurnal Edukasi dan Teknologi Pembelajaran, 2020.

Sopiatin, Popi. Manajemen Belajar Berbasis Kepuasan Siswa. Bogor: Ghalia Indonesia., 2010.

Yuliati, Ana, and Mariam Ulfa. "Pengembangan Bahan Ajar LKS Berorientasi Pendekatan Komunikatif Berbasis Tugas." Jurnal Universitas Muhammadiyah 2, no. 9 (2017): 189 - 203.

Zulkarnaen. Ilmu Menjual. Yogyakarta: Graha IImu, 2012 